\title{
Analyzing the Relationship between the Legend of Dōjōji and the Kabuki-Dance Kyōganoko Musume Döjojji to Develop Prototyping Systems
}

\author{
Miku Kawai ${ }^{1, *}$, Jumpei Ono ${ }^{2}$, Takashi Ogata ${ }^{3}$ \\ ${ }^{1}$ Faculty of Liberal Arts, The Open University of Japan, 2-11, Wakaba, Mihama, Chiba 261-8586, Japan \\ ${ }^{2}$ Faculty of Software and Information Technology, Aomori University, 2-10-1, Seishincho, Edogawa, Tokyo 134-0087, Japan \\ ${ }^{3}$ Faculty of Software and Information Science, Iwate Prefectural University, 152-52, Sugo, Takizawa, Iwate 020-0693, Japan
}

\section{ARTICLE INFO \\ Article History \\ Received 26 November 2020 \\ Accepted 17 June 2021

\author{
Keywords \\ Kabuki \\ Kyōganoko Musume Dōjōji \\ legend of Dōjōji \\ narrative generation \\ kabuki's stage performance \\ structure \\ story
}

\begin{abstract}
Using detailed analysis of the stage structure of the kabuki-dance Kyōganoko Musume Dōjōji, as well as the legend of Dōjōji that comprises the background of the kabuki-dance, we present a 2D simulation system that uses music, lyrics, and images. A prototype system was then developed that complements the above system based on Kyōganoko Musume Dōjōji using a 3D animation system based on the analysis of the storyline of the legend of Dōjojji, which serves as the origin of Kyoganoko Musume Dōjōji. In particular, we organize 11 scenes from Kyōganoko Musume Dōjōji and map them to six scenes from the legend of Dōjōji. In our prototype system, the latter scenes insert into the former scenes based on this mapping. This paper shows detailed analyses of two narrative contents and concretely describes system mechanisms according to these narrative analyses.
\end{abstract}

(C) 2021 The Authors. Published by Atlantis Press International B.V. This is an open access article distributed under the CC BY-NC 4.0 license (http://creativecommons.org/licenses/by-nc/4.0/).

\section{INTRODUCTION}

Kabuki is a representative cultural heritage in Japan that incorporates various types of performing arts from dance and classical performance, such as $n \bar{o}$ and kyōgen. Many studies have been conducted regarding its preservation and inheritance, and in recent years, there are also studies investigating kabuki from the viewpoint of technology.

For example, many studies of kabuki have examined the ways in which video technology has been introduced to performances. Some researchers have analyzed the preservation of "Shosagoto (the movements of actors)" using motion capture. For example, Oda and Genda [1] studied characteristic movements in kabuki using a motion capture system. Omoto et al. [2] created a model of Minamiza, a traditional kabuki theatre, in Kyōto. Kobayashi [3] focused on actor's movements, comparing Western dance in the ballet La sylphide with the Japanese dance Kyoganoko Musume Dōjōji to examine the creation of dances. Another study focused on "Furi (swing)," analyzing small movements such as walking and hand expressions [4]. Using a commercially available robot (desktop robot "Premade AI"), the stage of ningyō jōruri Hidakagawa Iriaizakura was also reproduced remotely by the Tokyo University of Technology. In contrast to these studies, we approached the narrative of kabuki from multiple different viewpoints.
Kyōganoko Musume Dōjōji [The Maiden at the Dōjōji Temple] is one of many works based on the "legend of Dōjōji", which has also been related in narratives and picture scrolls, and is a latter-day description of the legend of Anchin and Kiyohime. Dōjōji is a temple of the Tendai sect in Hidakachō, Hidaka, Wakayama, Japan. This temple is the subject of the legend of Dōjōji, which has been recorded for over a 1000 years. Although this legend has undergone many changes over its long history, it is still well known in Japan. Of the versions of this legend, we focus on the kabuki-dance Kyoganoko Musume Dōjoji, which is considered to represent the modern form of the legend of Dōjojji. We also examined the stage performance structure of Kyoganoko Musume Dōjōji and the storyline of the legend of Dōjōji.

Based on these narrative analyses, this paper describes the development of two prototyping systems: (1) a 2D animation system that reproduces the stage performance structure of Kyoganoko Musume Dōjoji and (2) a 3D animation system that complements the story of Kyōganoko Musume Dōjōji. Although the former system uses music, background, people, and the dance of Kyoganoko Musume Dōjojii, the dance is limited to a simple presentation, since the purpose of the system is to represent the entire stage performance structure. These two systems are related. In particular, we analyze the scenes of the legend of Dōjoji and associate them with the scenes of Kyōganoko Musume Dōjōji. The system based on the legend of Dōjōji complements the system based on the stage performance structure of Kyōganoko Musume Dōjōji to represent a somewhat complementary explanation using visual imagery. 
In previous research, we surveyed and analyzed Dōjoji story and Kyōganoko Musume Dōjōji in kabuki [5], and developed a first system to simulate the stage performance structure of Kyogganoko Musume Dōjōji [6]. We integrated narrative generation systems, including explanation generation, into the abovementioned simulation system [7]. This paper extends and integrates the previous analysis of Kyōganoko Musume Dōjōji and its systematization and aims to present a new idea regarding the system according to the storyline of the legend of Dojjoji to complement the former system. Although Kyōganoko Musume Dōjōji is a narrative work that was derived from the legend of Dōjōji, it does not directly describe the narrative of legend of Dōjoji. In the proposed complementary system, the simulation system based on Kyōganoko Musume Dōjōji and the narrative system according to the legend of Dojjoji are combined to ultimately aim users of the system to better understand the relationships between the two narratives and to ultimately enjoy the story of Dōjōji as a Japanese traditional narrative.

It is significant that this study treats kabuki as a research object and approaches the narrative of kabuki, which has not previously been surveyed and analyzed, from the viewpoint of systematization using the methods of artificial intelligence and cognitive science, specifically aiming at automated narrative generation. This is a challenge in intelligence system research, including artificial intelligence. In particular, kabuki is interesting in that it is a narrative collection of many Japanese traditional narratives. Moreover, in terms of the perspective of formulating a system, the narrative of kabuki is a somewhat complex system that includes complicated diverse narratives that can be expressed in multiple forms. Likewise, precise analysis of structures is an immensely important theme in research involving computer systems. Concerning our research on kabukis narrative generation, please refer [8-12].

Ultimately, the goal of our studies-including this paper-is automated narrative generation. Specifically, we aim to present the concept and idea of "narrative content works," including automated narrative generation function that did not previously exist and to develop a system according to this framework. Furthermore, in one of our future studies, we hope to incorporate the developed functions into robots [13]. In this paper, we state two types of narrative analyses, namely research that integrates previous analysis results of the stage structures of Kyōganoko Musume Dōjōji and research that analyzes the storyline of the legend of Dōjojij, which ultimately allows the development of two types of systems based on the analyses. Artificial intelligence, which this study centers on, is an engineering genre that has essential basis in cognitive science. Since the motivation of this study is to explore the framework of human intelligence, analyses of research objects using a variety of methods also serve as important steps in the development of artificial intelligence.

Although Kyōganoko Musume Dōjōji is a narrative work that was derived from the legend of Dōjōji, it does not directly describe the narrative of legend of Dōjoji. In the proposed complementary system, the simulation system based on Kyōganoko Musume Dōjōji and the narrative system according to the legend of Dojjoji are combined to ultimately allow users of the system to better understand the relationships between the two narratives and enjoy the story of Dōjōji as a Japanese traditional narrative.

We can readily demonstrate the structure of this paper. Section 2 introduces surveys and analyses of Kyōganoko Musume Dōjōji and the legend of Dōjōji. The former description corresponds to the summarization and extension of the previous research results. Moreover, Table 1 is a comprehensive table. In Section 3, we describe a $2 \mathrm{D}$ animation system based on the above analysis of Kyōganoko Musume Dōjōji, and the analysis is an extended version of one that we have previously sought. Section 4 describes a system in which the $3 \mathrm{D}$ animation system based on combining the analysis of the storyline of the legend of Dōjoji with the system in Section 2. Furthermore, in Section 5, we present problems with the developed system and indications for future directions. Section 6 is a summary of this paper.

\section{ANALYSES OF KYŌGANOKO MUSUME DŌJŌJI AND THE LEGEND OF DŌJŌJI}

In this section, we discuss the investigation and analyses of Kyōganoko Musume Dōjōji and the legend of Dōjōji.

\subsection{What is Kyōganoko Musume Dōjöji?}

Kyōganoko Musume Dōjojii is a representative work of kabuki dance that has been played by representative female onnagata such as Nakamura Utaemon VI and Tamasaburo Bando V. The ancient legend represented in Kyōganoko Musume Dōjōji was transmitted through Buddhist narratives, nō, texts, picture scrolls, and other means.

Kyōganoko Musume Dōjōji is a development of the legend of Anchin and Kiyohime. Unlike the Kiyohime legend, a woman's obsession is not the focus in this version, and various kimonos and props are used to show her daughter in love, making it a completed work of Musume Dōjojii as a kabuki dance. That is, it basically inherits the form of the nō Dōjojii intact, but the legend of Dōjōji is not specifically shown in the verse; a changing dance is central. Therefore, the story of the legend of Dōjojii is expressed only symbolically, and the narrative is weakened.

\subsection{Analyzing the Stage Performance Structure of Kyōganoko Musume Dōjōji}

Table 1 displays the elements of Kyogganoko Musume Dōjojii and the methods through which they are implemented. The table includes the following five items for each scene:

(1) [Actual stages] Flow and characteristics of the dance on stage (the contents in brackets indicate scene characteristics);

(2) [Music] Music used in the system, based on the Kineie Shamisen score [14], and created with a free composition tool ("Wagaku Hitosuji," https://jonkara.net/soft/wagaku/). However, the system uses the actual music because there are no scores for Michiyuki, Ranbyōshi, and Kaneiri. In other scenes, we only reproduced the music for the shamisen. Since the sound of the shamisen music feels higher than that on the actual stage, there is a lingering sense of discomfort compared with the actual music;

(3) [Lyrics] Excerpts from the beginning and end of the lyrics (only the Ranbyosshi is shown in full). The lyrics are Romanized because they are written in old Japanese; 

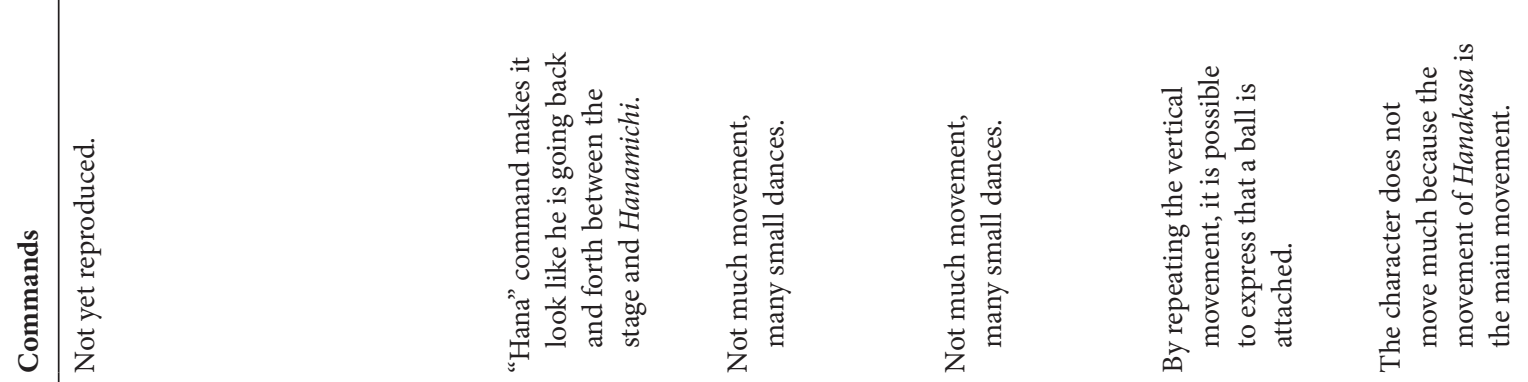

离

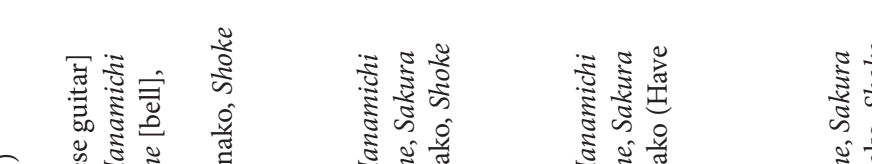

(

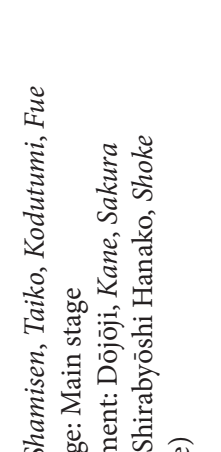

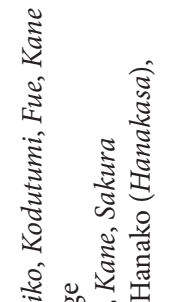

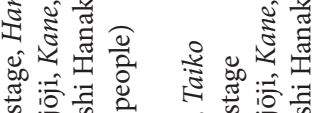

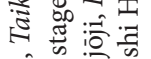

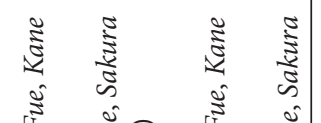

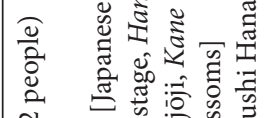

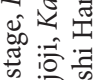

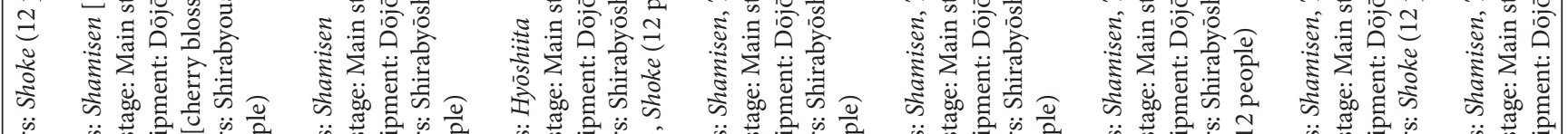

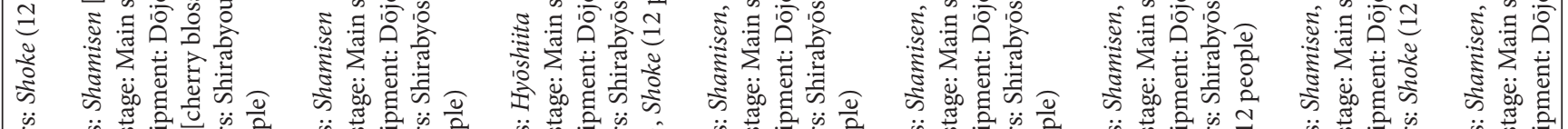

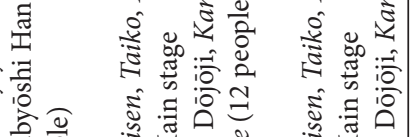

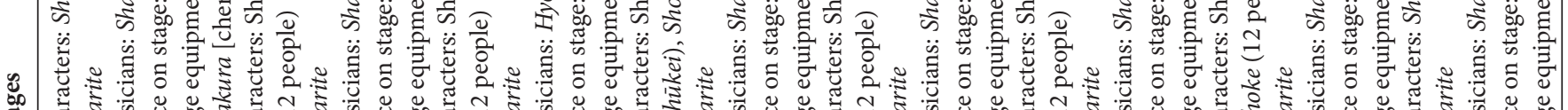

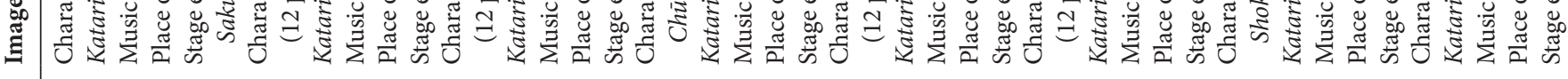

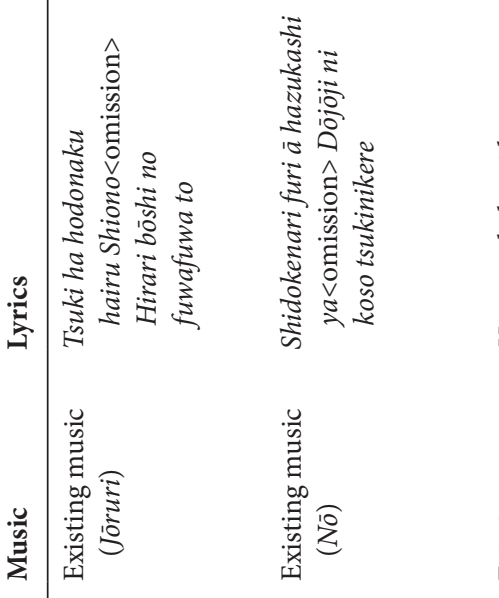

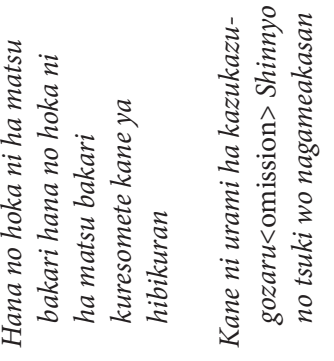

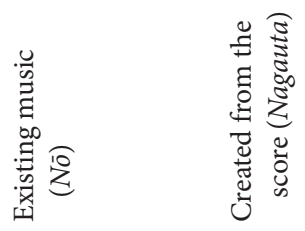

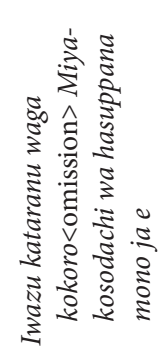

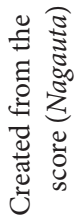

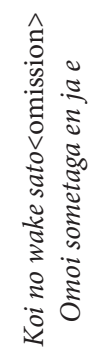

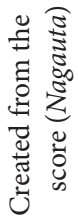

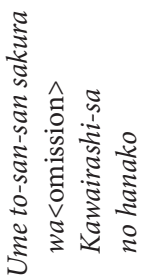

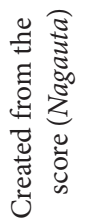

苞芯

客节

若

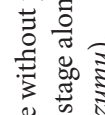

焉

苛

व

竎

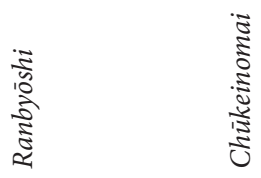

$\stackrel{\square}{\square}$

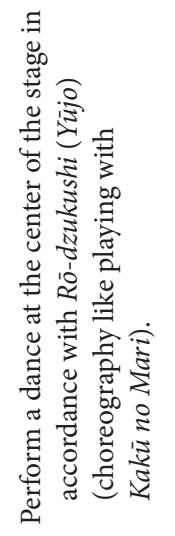

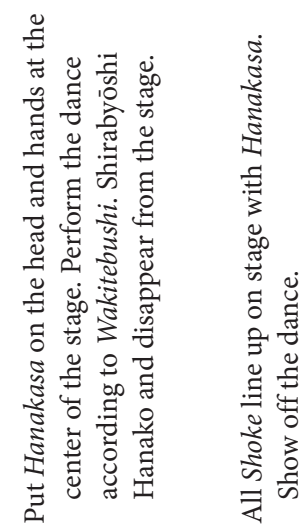

$\frac{2}{5}$ 


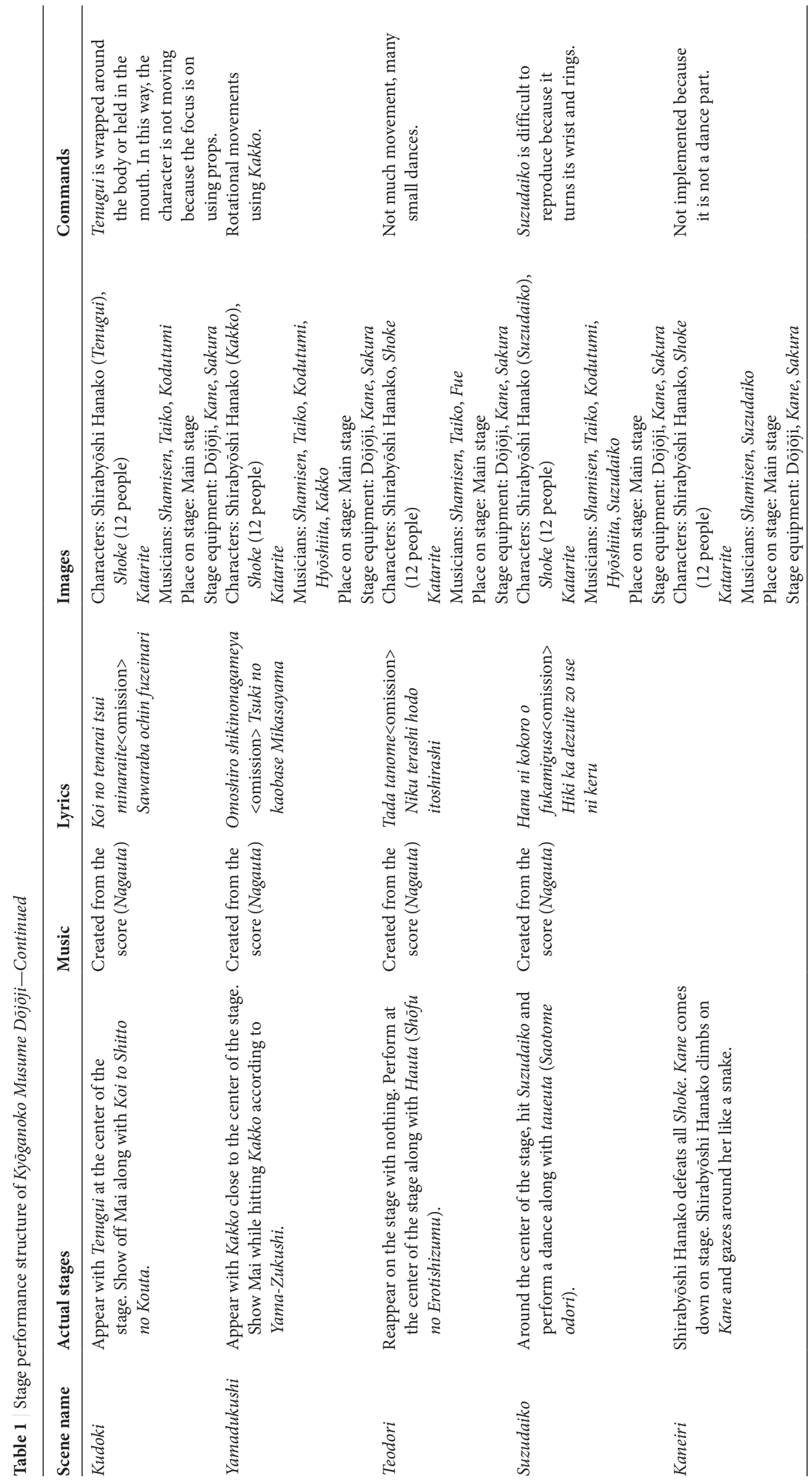


(4) [Images] Images of appearing characters, the main stage, and stage equipment. The props are listed in parentheses in the "Shirabyōshi Hanako";

(5) [Commands] The command is written in the code. Commands used in the system (input sentences instructing the reproduction system to create the character animation or the background).

\subsection{Analyzing the Narrative Structure of the Legend of Dōjōji}

The story of the legend of Dōjōji (also known as the legend of Anchin and Kiyohime) involves Kiyohime, a woman living in Kumano (the area covering a part of present Wakayama and Mie prefectures) who is betrayed by a Buddhist monk (Anchin). Her anger causes her to be transformed into a snake, and she burns the monk together with a bell in Dōjōji. Figure 1 presents a flowchart that summarizes the legend of Dōjōji. Figure 1 is based on three stories: Dainihonkoku Hokekyō Genki [15], Konjaku Monogatari Shū [16], and Dōjōji Engi [17].

In Figure 1, each box shows a scene, and the frame that summarizes multiple events shows a scene. The scene summarizes the events that occurred in the same place. In addition, the third scene has a branching structure that shows the small differences in the three quoted stories.

\section{THE SIMULATION SYSTEM BASED ON THE STRUCTURAL ANALYSIS OF KYŌGANOKO MUSUME DŌJŌJI}

Regarding the simulation system using 2D animation based on the above structural analysis of Kyōganoko Musume Dōjōji, we have published the idea and implementation $[6,18,19]$. In this paper, we completed the development of all of the scenes of Kyoganoko Musume Dōjōji to extend the system through the development of the first scene of Michiyuki.

As we mentioned in Section 1, our goal is to create a system that uses inputs to automatically generate a staging structure. This study presents the preliminary phase of this work. To study the system for automatic generation, we created an animation from the content shown in Table 1. This section first describes the animation tool, then discusses the flow used to create an animation.

This study uses the user interface of KOSERUBE [20], which has two modules. The first module converts the generated stories into animation code specific to KOSERUBE, based on which the second module plays the animation. Although this $2 \mathrm{D}$ animation system was developed using the previously mentioned KOSERUBE, KOSERUBE was originally a system that we developed with the aim of use in various application aims. Moreover, the $2 \mathrm{D}$ animation system in this paper also corresponds to an application system. In fact, the characters, music, stages, etc. used in this $2 \mathrm{D}$ system differ from the original KOSERUBE. In particular, the system utilizes the analysis results of Kyoganoko Musume Dōjōji. However, although KOSERUBE has the ability to automatically generate stories from defined elements, the 2D animation system in this paper currently does not have an automated narrative generation mechanism since its main objective is to directly simulate the stage structures of Kyogganoko Musume Dōjōji. In the future, the system will be able to acquire more intelligent narrative generation ability through utilizing the narrative generation mechanism of KOSERUBE and other methods and techniques that we are currently investigating.

The system reproduces a performance by combining a background and a character image with another image that imitates the play's stage. In addition, the music in Kyōganoko Musume Dōjōji, along with the text showing the story and lyrics, are displayed at the bottom of the screen. Our goal is not to produce computer graphics, but to reproduce the elements that make up the entire stage. For this reason, we do not pursue a realistic representation in our animations.

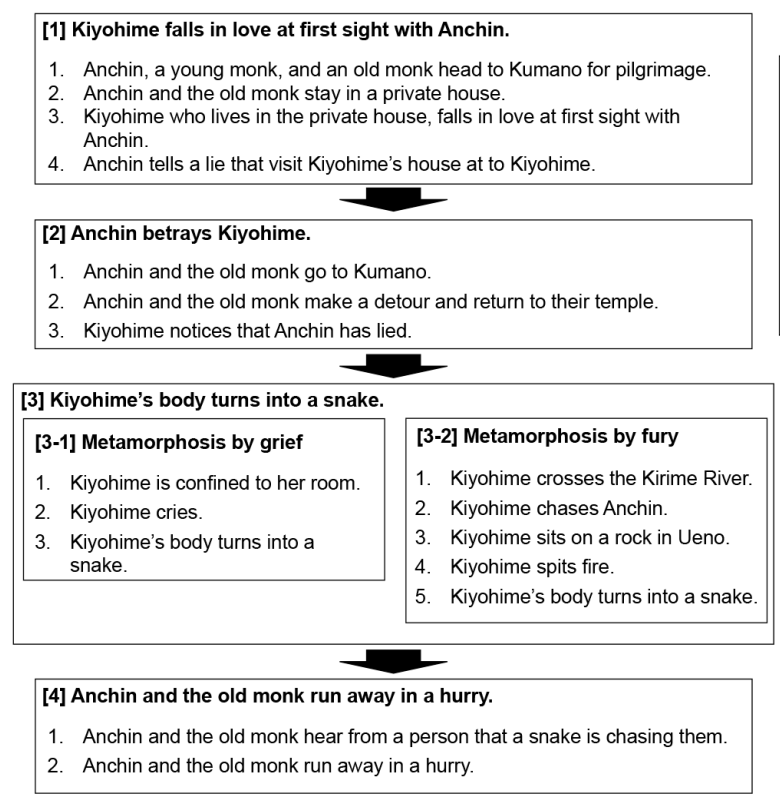

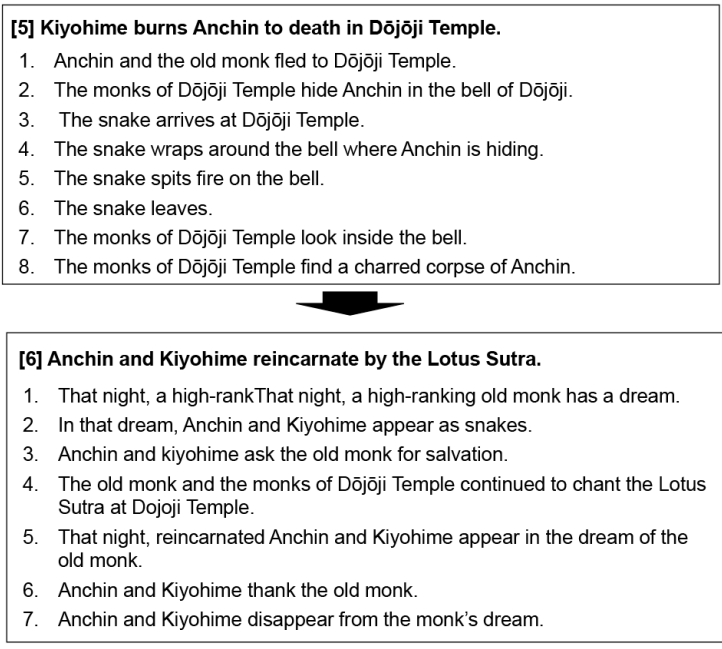

Figure 1 Flow chart of the legend of Dōjōji. 
Figures 2 and 3 present an example of an animation. As the scenes on the stage are largely divided into hanamichi and hon-butai (main stage), the figures portray these scenes (Figures 2 and 3 respectively show the main stage and hanamichi). The screen structure shown in Figures 2 and 3 use images from the KOSERUBE database to represent the background and characters on stage. The screen consists of four layers: text, character, stage, and background. Here, the dancing figures are the characters, and the instrumentalists, monks, and bells are depicted in the background.

The system uses two kinds of music: the music of the actual Kyōganoko Musume Dōjōji and the electronic music created from a musical score. The musical score used was Nagauta Kyōganoko Musume Dōjōji: Shamisen Bunka-fu by Kineie. To create the music, we used a free composition tool called "Wagaku Hitosuji."

\section{THE SYSTEM INTEGRATING THE STRUCTURAL STORY OF THE LEGEND OF DŌJŌJI WITH KYŌGANOKO MUSUME DŌJŌJI}

In Section 2, Kyōganoko Musume Dōjōji was described as representative of the legend of Dojojij; however, the stories are not explicitly the same. Therefore, we developed a system to complement the story of Kyōganoko Musume Dōjöji by using the story of the legend of Dōjōji [13]. This system is discussed below.

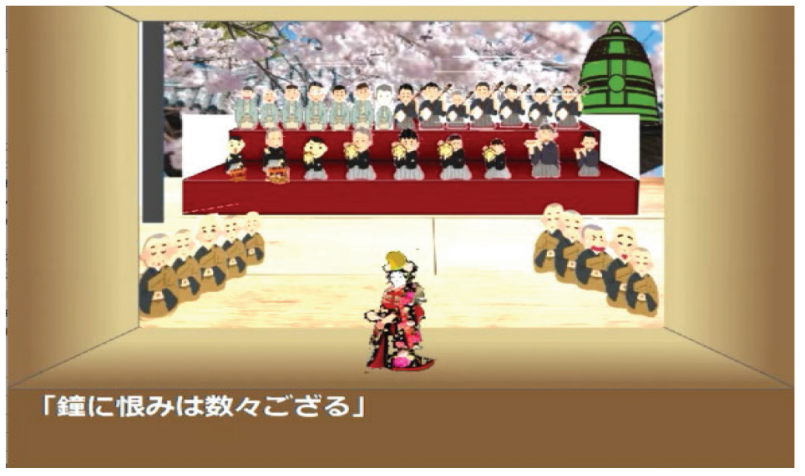

Figure 2 Example of a visualized stage performance structure ("Ranbyōshi").

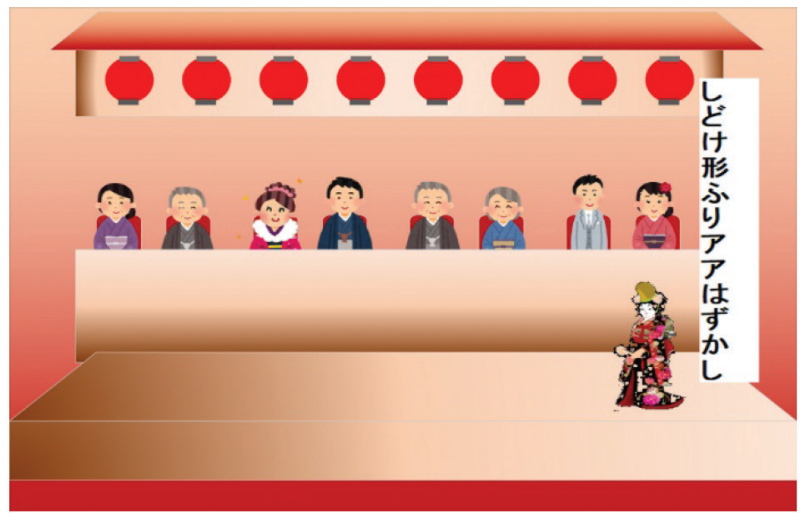

Figure 3 Example of a visualized stage performance structure ("Michiyuki").

\subsection{Analysis of Story Structure of the Legend of Dōjōji}

We analyzed the structure of scenes in the legend of Dōjōji based on three works that depict the legend. Figure 1 presents a flowchart created as a result of the analysis. Table 2 has detailed information on the narrative components of the event sequence described in Figure 1. In this table, "Scene" describes the titles of the scenes, "Components" lists the elements that appear in each scene, and "Events in Each Scene" divides each scene into sentences to demonstrate the flow of the story's events.

\subsection{Associating Kyōganoko Musume Dōjōji with the Legend of Dōjōji}

We associate the scene of the legend of Dōjoji with scenes from Kyogganoko Musume Dōjoji to use it for the rhetoric in which the memories of Anchin and Kiyohime are revived. Table 3 connects the legend of Dōjōji with the scenes of Kyōganoko Musume Dōjōji, using the eleven scenes that make up Kyōganoko Musume Dōjōji described by Watanabe [21] as the key. Scenes from the legend of Dōjōji are based on the structure shown in Figure 1. Eleven scenes of Kyōganoko Musume Dōjōji were classified into negative and positive.

At first glance, Kyōganoko Musume Dōjōji is played on a bright and flowery stage, and the heroine's clothes are also splendid. However, the legend of Dōjojji, which is the background story or origin of Kyogganoko Musume Dōjōji, is a dark story in that it is based on the heroine's dark emotions and resentment, which ultimately transform her into a snake so she can kill the man she blames for her negative emotions. Thus, these two narratives share common narrative material yet contrast in terms of presenting a bright versus a dark narrative. Furthermore, although Kyōganoko Musume Dōjōji is a bright narrative on the surface, characteristics of the original dark narrative sometimes appear through the heroine's actions and facial expressions. We associated the bright aspect that forms the underlying tone in Kyogganoko Musume Dōjōji with the positive side of the heroine's personality. In contrast, the dark aspect in Kyogganoko Musume Dōjōji is associated with the negative side of the heroine's personality. Although her negative personality is not distinguishable in bright scenes_-such as when she does a flowery dance with big flower hats in the scene of "Hanagasa_Odori"- she still exposes her true character and markedly glares at monks in the last scene of "Kaneiri" with heightened resentment to the ring.

A scene with negative verses such as a gesture of glaring at a bell or a grudge is considered a negative scene, and a bright scene is considered a positive scene. Of the six scenes from the legend of Dōjōji, one or more scenes are associated.

\subsection{Development of the Prototyping System}

Based on the correspondence of the scenes in Table 3, the scenes from Kyōganoko Musume Dōjōji can be extended using the scenes of the legend of Dōjōji according to using three methods. One involves inserting a fragmentary memory like a flashback that represents one event that constitutes a scene, another involves representing the entire scene, and the third involves representing the 
Table 2 Details of scenes in the Legend of Dōjōji

\begin{tabular}{|c|c|c|c|}
\hline Scene & Components & \multicolumn{2}{|l|}{ Events in each scene } \\
\hline $\begin{array}{l}\text { [1] Kiyohime falls in love with } \\
\text { Anchin at first sight. }\end{array}$ & $\begin{array}{l}\text { Characters: Anchin, Old monk, } \\
\text { Kiyohime }\end{array}$ & \multicolumn{2}{|c|}{ Anchin, a young monk, and an old monk head to Kumano on a pilgrimage. } \\
\hline & Locations: Murogun, Kiyohime's & \multirow{3}{*}{\multicolumn{2}{|c|}{$\begin{array}{l}\text { Anchin and the old monk stay in a private house. } \\
\text { Kiyohime, who lives in the private house, falls in love with Anchin at first } \\
\text { sight. }\end{array}$}} \\
\hline & House & & \\
\hline & Time: Afternoon, Night & & \\
\hline & Things: - & \multicolumn{2}{|c|}{ Anchin lies to Kiyohime about visiting Kiyohime’s house. } \\
\hline \multirow[t]{5}{*}{ [2] Anchin betrays Kiyohime. } & Characters: Anchin, Old monk, & \multirow{5}{*}{\multicolumn{2}{|c|}{$\begin{array}{l}\text { Anchin and the old monk go to Kumano. } \\
\text { Anchin and the old monk make a detour and return to their temple. } \\
\text { Kiyohime notices that Anchin lied. }\end{array}$}} \\
\hline & Kiyohime & & \\
\hline & Locations: Murogun, Kumano & & \\
\hline & Time: - & & \\
\hline & Things: - & & \\
\hline \multirow[t]{9}{*}{$\begin{array}{l}\text { [3] Kiyohime's body turns } \\
\text { into a snake. }\end{array}$} & $\begin{array}{l}\text { [3-1] Metamorphosis by grief } \\
\text { Characters: Kiyohime, Snake } \\
\text { (Kiyohime) }\end{array}$ & $\begin{array}{l}\text { [3-1] Kiyohime is confined to her } \\
\text { room. }\end{array}$ & $\begin{array}{l}\text { [3-2] Kiyohime crosses the Kirime } \\
\text { River. }\end{array}$ \\
\hline & Locations: Kiyohime's room & & \\
\hline & Time: - & \multirow{7}{*}{$\begin{array}{l}\text { Kiyohime cries. } \\
\text { Kiyohime's body turns into a snake. }\end{array}$} & Kiyohime chases Anchin. \\
\hline & Things: - & & Kiyohime sits on a rock in Ueno. \\
\hline & [3-2] Metamorphosis by fury & & \\
\hline & $\begin{array}{l}\text { Characters: Kiyohime, Snake } \\
\text { (Kiyohime) }\end{array}$ & & Kiyohime spits fire. \\
\hline & Locations: Kirime River & & Kiyohime's body turns into a snake. \\
\hline & Time: - & & \\
\hline & Things: - & & \\
\hline \multirow[t]{4}{*}{$\begin{array}{l}\text { [4] Anchin and the old monk } \\
\text { run away in a hurry. }\end{array}$} & $\begin{array}{l}\text { Characters: Anchin, Old monk, } \\
\text { Person, Snake (Kiyohime) }\end{array}$ & \multirow{2}{*}{\multicolumn{2}{|c|}{ Anchin and the old monk hear from a person that a snake is chasing them. }} \\
\hline & Locations: Murogun & & \\
\hline & Time: - & \multicolumn{2}{|c|}{ Anchin and the old monk run away in a hurry. } \\
\hline & Things: - & \multicolumn{2}{|c|}{ Anchin and the old monk flee to Dōjōji Temple. } \\
\hline \multirow[t]{4}{*}{$\begin{array}{l}\text { [5] Kiyohime burns Anchin to } \\
\text { death in Dōjōji Temple. }\end{array}$} & $\begin{array}{l}\text { Characters: Anchin, Old monk, } \\
\text { Snake (Kiyohime), Monks of } \\
\text { Dōjōji Temple }\end{array}$ & \multicolumn{2}{|c|}{ The monks of Dōjōji Temple hide Anchin in the bell of Dōjōji. } \\
\hline & Locations: Murogun, Dōjōji Temple & \multicolumn{2}{|l|}{ The snake arrives at Dōjōji Temple. } \\
\hline & Time: - & \multicolumn{2}{|c|}{ The snake wraps around the bell where Anchin is hiding. } \\
\hline & Things: Bell of Dōjōji & \multicolumn{2}{|l|}{ The snake spits fire on the bell. } \\
\hline \multirow[t]{10}{*}{$\begin{array}{l}\text { [6] Anchin and Kiyohime are } \\
\text { reincarnated through the } \\
\text { Lotus Sutra. }\end{array}$} & $\begin{array}{l}\text { Characters: High-ranking old monk, } \\
\text { Monks of Dōjōji Temple, Anchin, } \\
\text { Kiyohime }\end{array}$ & \multicolumn{2}{|l|}{ The snake leaves. } \\
\hline & Locations: Dōjōji Temple, Dream & \multicolumn{2}{|c|}{ The monks of Dōjōji Temple look inside the bell. } \\
\hline & Time: Afternoon, Night & \multicolumn{2}{|c|}{ The monks of Dōjōji Temple find Anchin's charred corpse. } \\
\hline & Things: The Lotus Sutra & \multicolumn{2}{|c|}{ That night, a high-ranking old monk has a dream. } \\
\hline & & \multicolumn{2}{|c|}{ In that dream, Anchin and Kiyohime appear as snakes. } \\
\hline & & \multicolumn{2}{|c|}{ Anchin and Kiyohime ask the old monk for salvation. } \\
\hline & & \multicolumn{2}{|c|}{$\begin{array}{l}\text { The old monk and the monks of Dōjōji Temple continue to chant the Lotus } \\
\text { Sutra at Dojoji Temple. }\end{array}$} \\
\hline & & \multicolumn{2}{|c|}{$\begin{array}{l}\text { That night, a reincarnated Anchin and Kiyohime appear in the old monk's } \\
\text { dreams. }\end{array}$} \\
\hline & & \multirow{2}{*}{\multicolumn{2}{|c|}{$\begin{array}{l}\text { Anchin and Kiyohime thank the old monk. } \\
\text { Anchin and Kiyohime disappear from the dream. }\end{array}$}} \\
\hline & & & \\
\hline
\end{tabular}

entire scene as a recollection. The numbers like [1], [2], and [5] correspond Table 2 . Table 3 is an incomplete example that uses only the first methods.

In the system that associates the simulation system of the stage performance structure of Kyōganoko Musume Dōjōji with the legend of Dōjojii, each scene in the legend of Dōjōji coincides with a scene of Kyōganoko Musume Dōjōji. To associate a scene of Kyōganoko Musume Dōjōji with a scene of the legend of Dōjōji, we focused on specific elements of lyrics and scenes as key information to better visualize a scene of the legend of Dōjōji according to keys. We defined three types of methods: (1) inserting a fragmentary memory, such as a flashback, which represents one event that constitutes a scene, (2) representing the entire scene in present time, and (3) representing the entire scene as a recollection. This method relates to studies regarding the methods in which various narrative elements outside of the elements of a current story are introduced into the current story. For example, Genette [22] proposed the narratology of narrative discourse, including the aforementioned methods, and we have applied narratology into our narrative generation research [23]. The methods mentioned are simplifications. 
In this prototyping system, how each scene of the legend of Dojojoji relates to a scene in Kyōganoko Musume Dōjōji by 2D animation is represented using $3 \mathrm{D}$ animation. Figures 4 and 5 portray examples of the two scenes. The "Michiyuki" scene corresponds to the scene in which Anchin hides in the bell, just before the scene shown in Figure 4 in which Anchin is burned. Figure 5 shows the scene of "Kaneiri," which corresponds to the scene in which Kiyohime burns Anchin. The "Kaneiri" scene corresponds to the scene in which Kiyohime is burning Anchin, and Kiyohime is blowing red fire into the bell.

In addition, we used MikumikuDance models related to Hatsune Miku, a vocaloid character, for the 3D models*.

\section{DISCUSSION}

\subsection{Problems}

The 3D animation consists of six scenes in total, four of which we have already created. Completing the remaining two scenes will allow us to express the legend of Dōjōji throughout Kyogganoko Musume Dōjōji. We have not yet implemented the representation of more fragmented scenes.

Moreover, there is a problem regarding the definition of each scene. For example, "scene [2]" in Figure 1 has the following three events:

Table 3 Correspondence between scenes in Kyōganoko Musume Dōjōji and the Legend of Dōjōji

\begin{tabular}{|c|c|c|}
\hline Scene in Kyōganoko Musume Dōjōji & Kokoro (mind) & Scene in the Legend of Dōjōji \\
\hline Michiyuki & Ghost (Jealousy) & $\begin{array}{l}\text { [1] Kiyohime burns Anchin to death in Dōjōji Temple./[6] Anchin and Kiyohime } \\
\text { reincarnate by the Lotus Sutra. }\end{array}$ \\
\hline Ranbyōshi & Girl & [1]Kiyohime falls in love at first sight with Anchin. \\
\hline Chükeinomai & Girl & [1] Kiyohime falls in love at first sight with Anchin. \\
\hline Teodori & Jealousy & [2]Anchin betrays Kiyohime./[4] Anchin and the old monk run away in a hurry. \\
\hline Mariuta & Girl & $\begin{array}{l}\text { [1] Kiyohime falls in love at first sight with Anchin./[6] Anchin and Kiyohime } \\
\text { reincarnate by the Lotus Sutra. }\end{array}$ \\
\hline Hanagasaodori & Girl & $\begin{array}{l}\text { [1] Kiyohime falls in love at first sight with Anchin./[6] Anchin and Kiyohime } \\
\text { reincarnate by the Lotus Sutra. }\end{array}$ \\
\hline Kudoki & Girl in love (Betrayed girl) & [1]Kiyohime falls in love at first sight with Anchin./[2] Anchin betrays Kiyohime. \\
\hline Yamadukushi & Girl & [1]Kiyohime falls in love at first sight with Anchin. \\
\hline Teodori (2) & Jealousy & [2]Anchin betrays Kiyohime./[4] Anchin and the old monk run away in a hurry. \\
\hline Suzudaiko & Girl & [2]Anchin betrays Kiyohime./[3] Kiyohime’s body turns into a snake. \\
\hline Kaneiri & True character & [5]Kiyohime burns Anchin to death in Dōjōji Temple. \\
\hline
\end{tabular}

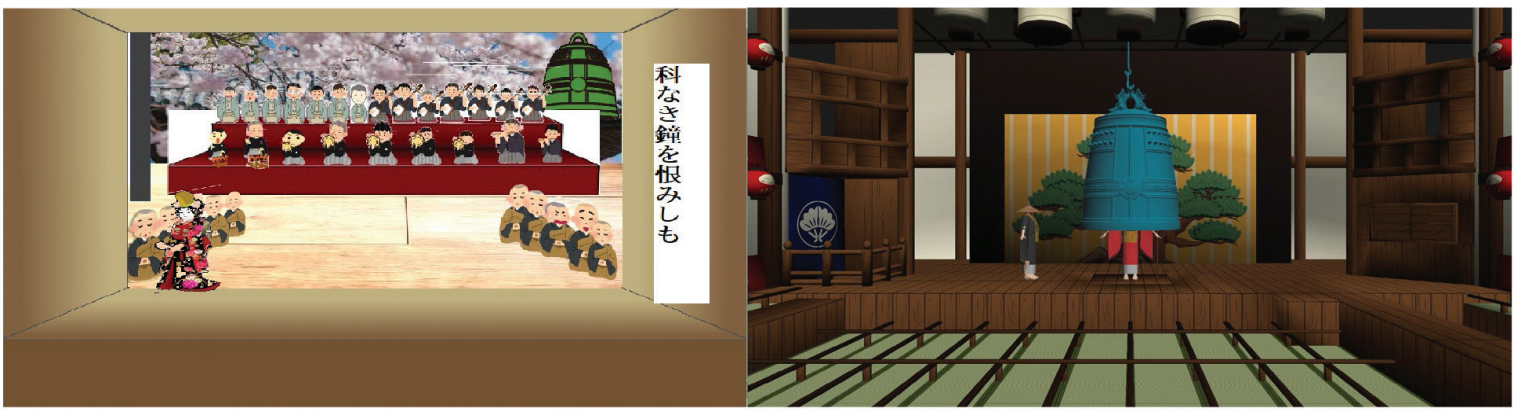

Figure 4 Michiyuki (left scene) and Anchin hiding in the bell (right scene).

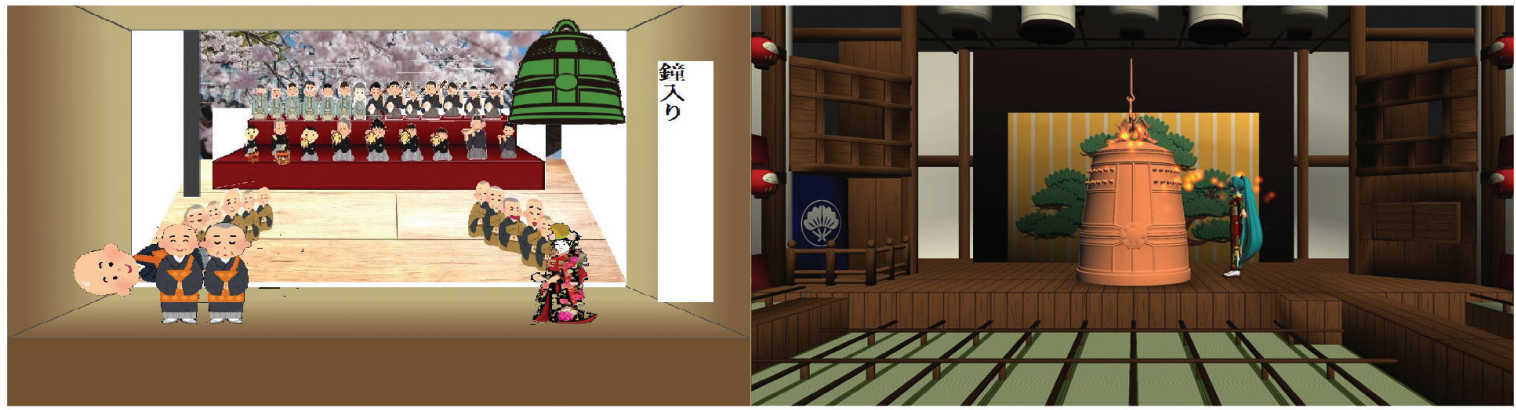

Figure 5 Kaneiri (left scene) and Kiyohime burning Anchin (right scene).

“Model: MMDモデル 初音ミク 振袖 ver. 2.0 [MMD Model Hatsune Miku Furisode ver. 2.0], Modeler: 金子卵黄 [Kaneko Ran'ou]

Model: よーでる僧 v. 0.1 (Yoderu_so v. 0.1), Modeler: ペニシス (細かすぎ P)

[Penishisu (Komakasugi P)]
Model: 和風劇場ステージ [Wafu_gekijo_sutegi], Modeler: いしころ [Ishikoro] Model: 紅葉の夜 ST20 [Momiji no Yoru ST20], Modeler: 怪獣対若大将 P [Kaiju tai Wakadaisho P]

Model: 般若面 ver. 1.00 (Han’nya_men ver. 1.00), Modeler: キッネッキ [Kitsune_tsuki] 
"Anchin and the old monk go to Kumano.", "Anchin and the old monk make a detour and return to their temple., and "Kiyohime notices that Anchin lied." Although these three events are represented as a scene in the current prototyping system, these need three different places: (1) the road of Anchin and the old monk, (2) the temple of Anchin and the old monk, and (3) Kiyohime's house. In the future, we are necessary to elaborately divide each scene into the corresponded places.

Since the differences between the negative and the positive scenes in inserted scenes of the legend of Dōjōji may be difficult to detect, we would like to consider mechanisms that can bring more clarity to users. For example, the simplest methods include changing the colors of the respective scenes.

Moreover, although the current insertion of the legend of Dōjōji into Kyōganoko Musume Dōjōji is automatically conducted by the system, we would like to consider alternative methodsincluding methods that involve interactions between the user and the system.

\subsection{Future Direction}

Recent years, kabuki practitioners have worked to incorporate video technologies like computer graphics into performances. During the COVID-19 pandemic, in fact, a new form of performance called "Zūmu Kabuki” was created. In "Zūmu Kabuki”, each actor is displayed on a video on the "Zoom" video calling app, and the videos are combined to form a single stage. This is also known as online kabuki. The Zümu Kabuki Chüshingura was performed from the end of June to the middle of July 2020. Kabuki has continued to develop with the utilization of artificial intelligence and digital technology.

Hatsune Miku and Nakamura Shidō co-starred in the "Nico Nico Chōkaigi, ${ }^{\dagger}$ in which a kabuki called Hana Kurabe Senbon-zakura was performed. This stage combined the world view of Hatsune Miku's representative song Senbonzakura with kabuki (Minamiza, Kyoto, August 2019). In addition, the ningyō jōruri Koimusume Tsumugi no Labyrince, using Hatsune Miku, was held at the Tomioka Silk Mill (Tomioka, Gunma, Japan/October 2020).

Currently, although this paper does not have relationships with actual kabuki content and related genres' content, it would certainly be more challenging to introduce previous methods that are more closely related to kabuki content, such as simply expressing existing kabuki's stories using computer graphics, etc.

\section{CONCLUSION}

In this paper, we first analyzed the stage performance structure of Kyōganoko Musume Dōjōji and its systematization through our animation tool. In particular, we analyzed and organized the stage performance structure, including elements such as musical instruments and stage backgrounds, and created a $2 \mathrm{D}$ animation

${ }^{\dagger}$ A festival organized by DWANGO Co. Ltd. "Chō Kabuki" was performed at the festival (https://chokabuki.jp/2019minamiza/english/). system using KOSERUBE. This analysis corresponds to the result in which our previous analysis of the stage performance structure of Kyōganoko Musume Dōjōji was revised and extended, and the extended version of the previous system includes all scenes of the analyzed Kyōganoko Musume Dōjōji.

Second, we have summarized the narrative structure of the legend of Dōjōji. As seen above, this paper analyzed the history and story of the legend of Dojjoji, focusing on the transformation of the legend of Dōjōji to Kyōganoko Musume Dōjōji and the personality of the characters. Moreover, we aimed to develop a prototyping 3D animation system that blends the legend of Dōjōji with Kyōganoko Musume Dōjōji. The narrative analysis of the legend of Dōjoji and its systematization serves as the first findings, based on the previous preliminary survey and concept.

As mentioned above, in this paper, we proposed a research that integrates the analysis of Kyogganoko Musume Dōjōji and its systematization and then formulate the analysis of the storyline of the legend of Dōjōji and its systematization into a framework.

\section{CONFLICTS OF INTEREST}

The authors declare they have no conflicts of interest.

\section{ACKNOWLEDGMENT}

The research for this chapter was supported by the Japan Society for the Promotion of Science (JSPS KAKENHI), Grant No. 18K18509.

\section{REFERENCES}

[1] I. Oda, E. Genda, Record of Characteristic Motion of the Kabuki Using the Motion Capture System, Proceedings of the Annual Conference of Japanese Society for the Science of Design, 51st Japanese Society for the Science of Design, Hachiouji, Tokyo, Japan, 2004, pp. 142-143.

[2] N. Omoto, K. Hasegawa, H. Motojima, S. Nagata, S. Tanaka, 3D model of Kyoto Minami-za theater and its application, Proceedings of the IPSJ SIG Computers and the Humanities, Information Processing Society of Japan, Tokyo, Japan, 2004, pp. 109-112.

[3] S. Kobayashi, Approach to choreography "Kiyohime": a comparative study of Japanese traditional dance and western ballet for female, Doctoral dissertation, Osaka University of Arts, 2018.

[4] R. Dong, Y. Chen, D. Cai, S. Nakagawa, T. Higaki, N. Asai, Robot motion design using bunraku emotional expressions - focusing on Jo-Ha-Kyū in sounds and movements, Adv. Robot. 34 (2019), 299-312.

[5] M. Kawai, J. Ono, T. Ogata, Analysis and Generation of the Narrative Elements in a "Dojoji" Story, Proceedings of the 3rd International Conference on Computational Intelligence and Intelligent Systems, New York, NY, 2020, pp. 44-45.

[6] M. Kawai, J. Ono, T. Ogata, Analyzing the stage performance structure of a Kabuki-Dance, Kyōganoko Musume Dōjōji, using 
an animation system, in: E. Ishita, N.L.S. Pang, L. Zhou (Eds.), Digital Libraries at Times of Massive Societal Transition (LNCS 12504), Springer Nature, Switzerland, 2020, pp. 248-254.

[7] J. Ono, M. Kawai, T. Ogata, Implementation of an Explanation Generation Mechanism Using Attribute Frames and a Noun Conceptual Dictionary, Proceedings of the 3rd International Conference on Computational Intelligence and Intelligent Systems, New York, NY, 2020, pp. 48-50.

[8] T. Ogata, Kabuki as multiple narrative structures, in: T. Ogata, T. Akimoto (Eds.), Computational and Cognitive Approaches to Narratology, IGI Global, Hershey, PA, 2016, pp. 391-422.

[9] T. Ogata, An integrated approach to narrative generation: from Mishima and Kabuki to narrative generation systems, in: T. Ogata, S. Asakawa (Eds.), Content Generation Through Narrative Communication and Simulation, IGI Global, Hershey, PA, 2018, pp. 49-147.

[10] T. Ogata. Kabuki as multiple narrative structures and narrative generation, in: T. Ogata, T. Akimoto (Eds.), Post-Narratology Through Computational and Cognitive Approaches, IGI Global, Hershey, PA, 2019, pp. 192-275.

[11] T. Ogata., Kabuki as a synthetic narrative: synthesis and expansion, in: T. Ogata (Ed.), Internal and External Narrative Generation Based on Post-Narratology: Emerging Research and Opportunities, IGI Global, Hershey, PA, 2020, pp. 109-254.

[12] T. Ogata, The narrative generation of Kabuki, Impact 2020 (2020), 68-70.

[13] M. Kawai, J. Ono, T. Ogata, Dual Story Generation Based on Love and Extreme Emotions, Proceedings of the 5th International Congress on Love \& Sex with Robots, Online, 2020.

[14] Y. Kineie IV, Nagauta Kyōganoko Musume Dōjōji: Shamisen Bunka Fu, 75th edition, Hōgakusha, Tokyo, Japan, 2018, pp. $174-177$.

\section{AUTHORS INTRODUCTION}

\section{Ms. Miku Kawai}

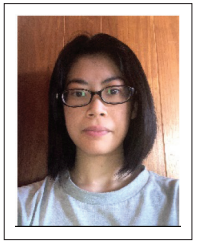

She was an undergraduate student at the Faculty of Software and Information Science, Iwate Prefectural University from 2018 to 2020 . She is an undergraduate student at Faculty of Liberal Arts, The Open University of Japan since 2021.

\section{Dr. Jumpei Ono}

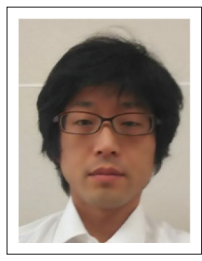

He received his Bachelor in Faculty School of Software and Information Science from Iwate Prefectural University in 2010. He received his M.S. degree and his PhD in Graduate School of Software and Information Science from Iwate Prefectural University in 2014 and 2018. He had worked as information and communication technology instructor at Vocational School of Digital Arts Sendai since 2018. He is Assistant Professor of the Faculty of Software and Information Technology at Aomori University since 2020.
[15] Chingen, Dainihonkoku Hokekyō Genki, in: M. Inoue, S. Ōsone (Eds.), Ōjōden Hokegenki, Iwanami Shoten, Tokyo, Japan, 1974, pp. 43-219.

[16] K. Mabuchi, F. Kunisaki, T. Konno, Konjaku Monogatari Shū, vol. 1, Shōgakukan, Tokyo, Japan, 1999.

[17] K. Mabuchi, Color Dōjōji Engi, vols. 1-2, in: T. Ouga, M. Gunji, Y. Enomoto, S. Shibasaki (Eds.), Dōjōji, Shōgakukan, Tokyo, Japan, 1983, pp. 9-16, 33-40.

[18] M. Kawai, J. Ono, T. Ogata, Analyzing the Stage Performance Structure of Kabuki-dance "Kyōganoko Musume Dōjōji", Proceedings of the 34th Annual Conference of the Japanese Society for Artificial Intelligence, Tokyo, Japan, 2020, 3D1-OS-22a-04.

[19] M. Kawai, J. Ono, T. Ogata, The Stage Structure of a Kabukidance: Survey, Analysis, and Representation of Kyoganoko Musume Dojoji, Proceedings of the 37th Annual Meeting of Japanese Cognitive Science Society, 2020, pp. 720-729.

[20] S. Imabuchi, T. Akimoto, J. Ono, T. Ogata, KOSERUBE: an application system with a propp-based story grammar and other narrative generation techniques, Proceedings of the 6 th International Conference on Soft Computing and Intelligent Systems and The 13th International Symposium on Advanced Intelligent Systems, IEEE, Kobe, Japan, 2012, pp. 248-253.

[21] T. Watanabe, Musume Dōjōji, Shinshindō, Tokyo, 1986.

[22] T. Akimoto, T. Ogata, A narratological approach for narrative discourse: implementation and evaluation of the system based on Genette and Jauss, in: N. Miyake, D. Peebles, R.P. Cooper (Eds.), Proceedings of the 34th Annual Conference of the Cognitive Science Society, vol. 34, Cognitive Science Society, Austin, TX, 2012, pp. 1272-1277.

[23] T. Ogata, Toward the consistent simulation of narrative discourse based on narratology, Proceedings of the 9th International Symposium on Artificial Life and Robotics, 2004, pp. 579-584.

\section{Dr. Takashi Ogata}

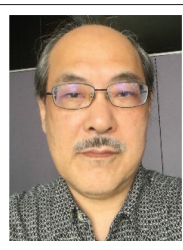

He received his Bachelor of Social Science in Waseda University in 1983, his M.S. in Tsukuba University in 1992, and his $\mathrm{PhD}$ in the University of Tokyo in 1995. He has industrial experience since 1983 at software development companies. Having experienced Associate Professor of the Faculty of Engineering at Yamanashi University since 1997, he is Professor of the Faculty of Software and Information Science at Iwate Prefectural University since 2005 . 